\title{
SELLING INSECURITY VIA TWITTER: UKRAINIAN PRESIDENT'S POSTS AND MODERN POLITICAL DISCOURSE
}

War and military conflict have been effectively framed by politicians in the $21^{\text {st }}$ century, beginning with the War on Terror (Entman, 2003). Social networks provide politicians with additional means to influence citizens' attitudes towards war, and spread the politics of resentment (Fukuyama, 2018). There is thus a strong need to study politicians' representations of war and conflicts on social networks on both academic and media-critical levels.

Modern scholars are deeply concerned about Trump's Twitter case; Twitter, Facebook and Instagram accounts of other Western leaders are also studied. However, political communication in the so-called developing countries isn't so well-researched. Thus, quite different approaches towards communication via social networks may be discovered. Among these countries, Ukraine, - a post-Soviet state that faced annexation and occupation of its territories, - is a particularly interesting one.

In Ukraine, social networks, especially Russian Vkontakte, Facebook and Twitter, were employed as fields of harsh discussions, both for information and for propaganda spreading during the Euromaidan. Ukrainian and international politicians, experts, journalists, and activists were deeply involved in the discussion. As a result, many new charismatic leaders emerged, - such as officials elected to the Ukrainian parliament - Verkhovna Rada - in 2015, - while others influenced Ukrainian politics as active members of civil society. The participation of American and Russian political technologists (Manafort, Surkov and others) increased the level of tensions, exploiting potentials of social networks to disseminate manipulative messages, fakes, calls to violence; bot armies were also involved. After the 2014 Maidan Revolution in Ukraine, social networks have been used as one of major means of political influence. However, the standards of political communication were compromised with both - post-Soviet customs and present dirty reality of hybrid war and the post-truth era.

Nowadays, with Russian social networks banned for security reasons in 2017, Facebook and Instagram are the most used online platforms in Ukraine. Twitter, similarly with the Polish and the Hungarian case (Matuszewski, Szabó, 2019), is used as a field for "elite" communication, with Ukrainian politicians, diplomats, experts and journalists taking part. During the "Revolution of Dignity" these platforms were used by Ukrainians to share "European" inclinations, encourage "pro-Western" affiliation. This approach was developed by the new president Poroshenko, Ukrainian diplomats and all ministries. 
Herein, by analyzing the Twitter account of former Ukrainian president Poroshenko, one can see how the Russian-Ukrainian war ("the aggression" in official discourse) is presented in President's posts in the pre-election period, when politicians usually actively use social networks. In this case it's possible to compare several periods: the period of the Azov Crisis ${ }^{1}$ and implementation of martial law, and the periods of three pre-election campaigns (before the first and the second round of presidential elections and before the early parliamentary elections). In a time of political discourse marketization (Thompson, 2016), foreign aggression and national insecurity are powerful messages to attract attention and influence voters' perceptions. Thus, the messages may be used not only for straightforward description of current events. References to acts of aggression and current insecurity may grow to become a kind of political capital. As far as Russian aggression and capability to resist Putin were the core themes for Poroshenko's pre-election agenda, the hypothesis of this research is as follows:

Two manners of exploitation of the theme of aggression can be found in the $5^{\text {th }}$ Ukrainian president's tweeting: with justification (with a clear newsbreak) and without any, the first type of being published during the hot phase of the conflict, the second one afterwards. Additionally, it's assumed that there is a possibility to design a technique for Tweet newsbreak definition and newsbreak type analysis with both machine and some manual processing.

Moreover, the analysis would help us compare Poroshenko's tweeting style and differentiate his role as Ukrainian security/insecurity dialogue moderator.

To study the character of Poroshenko's tweeting in several different periods, Tweets mentioning aggression were collected. Intensity of the Tweets was considered. Additionally, language justification in the Tweets was studied.

\section{MODERN POLITICAL DISCOURSE AND COMMUNICATION ON TWITTER}

Social networks have been challenging both content and form of communication and political discourse, "brought a new dimension to the mediation process between media and politics" (Dogu, Mat, 2019). Nowadays these tools are essential for political communication (Tari, Emamzadeh, 2018) globally (Bossetta, 2018).

The platforms provide politicians with new tools to "shape political discourse" (Genovese, 2019), to influence elections (Schneiker, 2019) or directly "win votes" (Spierings, Jacobs, 2019; Villar, María, 2019).

Social networks have been undermining the traditional channels of political information broadcast because of their "accessibility and availability" (Schneiker, 2019), inexpensiveness, simplicity and rapidity of message spreading (Matuszewski, Szabó,

${ }^{1}$ On the $25^{\text {th }}$ of November Ukrainian ships with crew were captured by Russian navy in the Kerch strait. The Russian side accused Ukrainian sailors of illegal entrance into Russian waters, the Ukrainian side claims there was no wrongdoing and that the Russian side was informed about the movement beforehand. On the 25th of May, according to the decision of the International Tribunal for the Law of the Sea, Russia must release the sailors. The Russian side, however, claimed that the Tribunal doesn't have jurisdiction in this case. 
2019), "ability to debate in real time" (López-Rabadán, Mellado, 2019), "the word-ofmouth-like nature" (Guerrero-Solé, 2018) and the potential to directly communicate with large audiences (Pérez-Curiel, Naharro, 2019). Twitter and other social media give a possibility to omit selection mechanisms of mass media and their "gate-keeping role" (Stetka, Surowiec, 2019). Twitter may be used by some politicians for "an ongoing press conference" (McGranahan, 2019) and is an important tool for political campaigns (Lee, $\mathrm{Xu}, 2018$ ). Moreover, mass media depend on popular politicians' posts and regularly reprint them (Blassnig, et al., 2019) (Ernst, et al., 2019) and include the whole posts in their news writing (Broersma, Graham, 2013; Heiss, et al., 2019) "with little journalistic mediation" (López-Rabadán, Mellado, 2019).

Political discourse becomes more personalized (Pérez-Curiel, Naharro, 2019), emotional and unpredictable (Schneiker, 2019). Authentic language and amateurism seem more effective on Twitter (Pain, Chen, 2019), where politics is mixed with entertainment (Pain, Chen, 2019). The main characteristics of tweeting are "impulsive," "impolite," "uncivil" (Ott, 2017). Additionally, emotional Tweets are shared more frequently than rational ones (Park, Kaye, 2019) and "attack Tweets" are more favored by the public (Lee, Xu, 2018). As a form of mediated communication, Twitter normalizes "the breaking of rules" (Schneiker, 2019), violation of journalistic standards of objectivity and responsibility in particular (Pérez-Curiel, Naharro, 2019), attacks and insults, negativity (Lee, Xu, 2018), disparagement of others (Ott, 2017). As a result, Twitter discussions "polarize" the political discourse (Matuszewski, Szabó, 2019), "may increase existing gaps between citizens at the left and the right ideological end" (Heiss, et al., 2019). Social networks may be used not only for collaboration, but "for argument and antagonism, including hate speech" and some politicians normalize extremism and racism in communication (McGranahan, 2019).

Both Twitter and Facebook are suitable for spreading populist messages; Facebook, however, offers more possibilities. Twitter audience is more professionalized; the platform is considered to be a sphere for "elite communication" (Matuszewski, Szabó, 2019). Facebook usually involves more ordinary people (Ernst, et al., 2019), and is more often used for political campaigning (Bossetta, 2018).

A politician becomes "a political product that is marketed through political branding" (Schneiker, 2019; Pérez-Curiel, Naharro, 2019) and there is a clear tendency towards marketization of politics; as a result, some politicians ignore the ideology and choose words that sell better (Thompson, 2016). The field of mass communication is highly competitive, and the process of gaining public attention is extremely complicated (Zhang, et al., 2019). "The power to attract an audience" is more important than "the power to communicate" (Zhang, et al., 2018), and a "story" is more significant than "a news source" (Tari, Emamzadeh, 2018).

Politicians directly communicate with citizens, choosing the correct sentences to persuade them, building a closer connection with the general public (Schneiker, 2019). They tell about their day-to-day activity, raising expectations (Schneiker, 2019) and retweet users' posts they like (Pain, Chen, 2019).

However, politicians generally don't interact with common people (Schneiker, 2019; McLaughlin, 2019; Stetka, Surowiec, 2019), regardless of the number of followers (Pain, Chen, 2019). As a rule, they don't use such tools as Retweets, mentions, 
likes etc. (Guerrero-Solé, 2018). The character of Twitter exploitation is mainly "selfreferential" (Garcia-Ortega, Zugasti-Azagra, 2018). Citizens' supposedly active role is just an "impression" (Cappelletti, 2019).

All these peculiarities of political discussion are used worldwide and do not depend on the political system, level of economic growth, freedom, and civil rights compliance. However, there is also a strong need to understand how this new type of political communication functions not only in pre-election period, but also in times of military conflicts or clashes.

\section{MATERIAL AND METHOD}

Poroshenko's Tweets from his official account, https://twitter.com/poroshenko, were content analyzed between November 2018 to July 2019. With the help of Vicinitas Twitter analysis tool, a total of 2519 Tweets (Ukrainian, text only) were observed.

\section{The period}

The period was chosen because of the intensity of events in Ukrainian politics:

- On the $25^{\text {th }}$ of November, the Azov Sea Incident a. k. a. the Kerch Strait Incident took place;

- Martial law was implemented in Ukraine $\left(26^{\text {th }}\right.$ of November-26 $6^{\text {th }}$ of December 2018 in 10 Ukrainian regions);

- On the $31^{\text {st }}$ of December, the pre-election campaign before the first round of the elections started, with the first round being held on the $31^{\text {st }}$ of March;

- On the $1^{\text {st }}$ of April, the second campaign was launched, before the second round, with elections on the $21^{\text {st }}$ of April;

- On the $20^{\text {th }}$ of May, after the dissolution of the Parliament, early parliamentary elections were announced by new Ukrainian president Volodymyr Zelensky;

- On the $21^{\text {st }}$ of July, the early parliamentary elections were held.

The words "aggression," "aggressor," "aggressive"2 were the subject of this research interest. A Python program (module 're') was used with a simple regular ex-

${ }^{2}$ There were harsh discussions in Ukraine about Russian-Ukrainian military conflict's naming - definitely an example of hybrid war undermining the understanding of reality. In Ukraine there were two opposing paradigms of the conflict's perception: "the war of Russia against Ukraine" and "the civil war on Donbas." As for the official naming, at first terrorism was mentioned - as in "the Anti-Terrorist Operation" (so in this official interpretation, Russian military and separatists were not included; there was just an operation with the aim to "terminate" some terrorists). The operation was subsequently renamed on the $30^{\text {th }}$ of April 2018 as "Joint Forces Operation." The aim of the "operation" was thus changed from "terrorists" to the characteristics of the combatants. The term "occupation" is also used in modern Ukrainian legislature. For instance, Law of Ukraine "On Ensuring Civil Rights and Freedoms, and the Legal Regime on the Temporarily Occupied Territory of Ukraine" was signed on the $27^{\text {th }}$ of April 2014. Former president writes his posts within this official paradigm. Russia is definitely Ukraine's enemy number one, according to his Twitter writing; however, he interprets the military conflict mainly as "aggression" and uses the term "war" rarely. Thus, the term "aggression" was analyzed. 
pression in Ukrainian '[Aa]hres $\mathrm{w}^{+}$' (transliterated). 234 Tweets containing the expression were found.

\section{Language justification and newsbreak}

As far as responsibility and justification for word choice should be an important part of official political discourse, we used a journalistic technique to evaluate this.

In journalism, one should prove the newsworthiness of a news item and the concept of "newsbreak" should be considered. Newsbreak is justification of a topic or clear evidence of the importance of the topic to society and the audience. Additionally, in journalism newsbreak should reference a source. According to BBC, "proper language is significant, especially in the times of war" (BBC, 2019).

To define a newsbreak in a Tweet, both the purpose of the mentioned word "aggression" and the source of information were identified.

Several types of other newsbreaks were discovered:

- Reaction to Ukrainian/international events or politicians' claims;

- Official visits, meetings, interviews, forums, discussions, telephone conversations;

- Law signings, orders or other Poroshenko's actions;

- Rituals: celebrations, anniversaries, honoring fallen Ukrainian military, citizens on occupied territory;

- Data and statistics;

To formalize the content analysis, several vocabularies were designed:

- political actors (subjects, institutions, countries), who participated in the political discussion about Ukraine, like NATO, UN, Stoltenberg, Merkel, Erdogan, Lithuania, the USA, Turkey etc.;

- "Azov Crisis" - related keywords, like: Azov Pact, sanctions, martial law, Kerch, mobilization, RF passports, etc.;

- official events identifiers, like: meeting, telephone conversation, journalists, interview, discussion, forum, visit, gathering etc.; additionally, a list of Ukrainian and foreign cities visited by Poroshenko was included;

- official actions identifiers, like: law, sign, approve, order, report; additionally, a list of Ukrainian political institutions involved in the conflict was added (Parliament, Security Council, local administrations etc.);

- "ritual" words and expressions, names of historical events, like: congratulate, celebrate, commemorate, glory, heroes never die, thank, pray etc.;

- data and statistics usage identifiers, like: \%, numbers with specification (thousand, million, people), data, statistic.

Tweets without the words from the vocabularies were additionally reviewed manually, and some Tweets were added to the proposed categories.

As for limitations, Tweets with Russian political actor mentions didn't follow the analysis logic, where actor mention means newsbreak is present. Putin and some Russian institutions like courts or special services, for instance, were used metaphorically quite frequently. Thus, the Tweets were sorted manually as well.

Thus, through the presence of a newsbreak, its type and the dynamic of mentions of the "aggression" were analyzed. 


\section{RESULTS: THE DYNAMICS OF "AGGRESSIVE" TWEETS}

Let's see the dynamics of the mentions: we can define three types of Poroshenko's involvement in the discussion of the topic. Here are seven charts in the course of seven months (number of mentions vertically, days horizontally) (Fig. 1).

\section{Fig. 1. Poroshenko's "aggressive" Tweets}

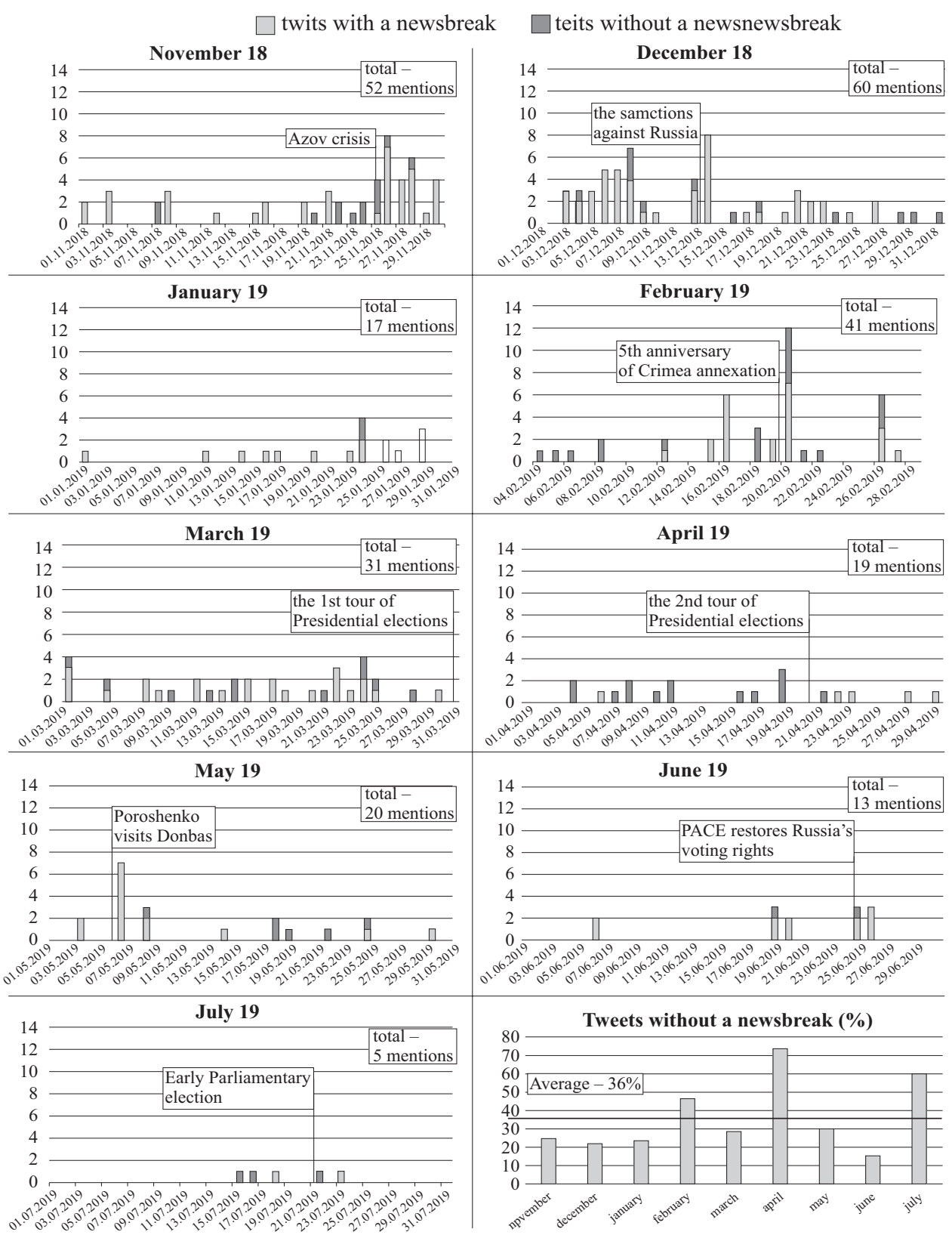

Source: Content analysis of Poroshenko's Tweets collected with Vicinitas Twitter analysis tool on August 2, 2019. 
As we can see, there are different characters of mentions defined as follows:

- The period of high constant attention (with large number and high intensity of mentions) between $25^{\text {th }}$ of November- $6^{\text {th }}$ of December - during the crisis;

- The periods of high sporadic attention, associated mainly with specifically created news events - the $5^{\text {th }}$ anniversary of Crimea annexation, Poroshenko's visits, meetings, statements about sanctions: $11^{\text {th }}-12^{\text {th }}$ of December; $16^{\text {th }}, 20^{\text {th }}, 26^{\text {th }}$ of February; $6^{\text {th }}$ of May;

- The periods of low constant attention (with small number of mentions (1-3) per $1-3$ days): $1^{\text {st }}-25^{\text {th }}$ of November; $15^{\text {th }}-31^{\text {st }}$ of December; $10^{\text {th }}$ of January-1 $9^{\text {th }}$ of April;

- The periods of low attention (after $19^{\text {th }}$ of April) and the periods of silence in January, June and July.

Data shows that in Poroshenko's Twitter, breaking or hot news such as the Azov Sea conflict are used for dense tweeting. There are also three periods of silence which may be observed during holidays and summertime.

There is no clear distinction between the "hot" phase of the conflict with Tweets, containing newsbreaks, and "calm" phase with Tweets without newsbreaks. As a rule, the two types of Tweets are used.

We may suppose (and will be able to confirm this later) that for the periods when there are no hot topics to draw attention to, special events were designated (celebrations, anniversaries etc.). In this case we may define specially created attention. When a politician or a political issue should be included into agenda, constant attention is important. However, sometimes newsworthiness may be ignored (for instance, in April or in February).

Thus, this case additionally demonstrates that Twitter becomes a suitable field for polarization, expressive language and attacks in political discourse. Known as dzhynsá (“jeans-ah", from Ukrainian for jeans - dzhýnsy), which means disguised paid-for material, the phenomenon has emerged between political figures through social network utilization. Constant reflections about the aggression and insecurity before elections helps to instill fear in voters and use the politics of resentment (Fukuyama, 2018).

\section{RESULTS: THE TYPES OF NEWSBREAKS IN POROSHENKO'S TWITTER}

The newsbreaks about Poroshenko's meetings with international leaders, visits to foreign countries, and internal visits were the most popular (see fig. 2).

The list of international leaders and political institutions contacted by Poroshenko and mentioned in the Tweets contains 26 positions, among which such politicians as Merkel, Tusk, Grybauskaite are the most popular. Poroshenko positioned himself as an equal member of communication about Ukraine with the help of generic statements such as "Together with Mrs. Chancellor made a clear statement..." or "got assurance from@mike_pence.”

However, concerning Russia, only a few political actors were mentioned. This helps to create both the atmosphere of Russian isolation and the image of Ukraine and its leader integrated with world community. Another point is, other Ukrainian politi- 
Fig. 2. Poroshenko's Tweets: newsbreak types

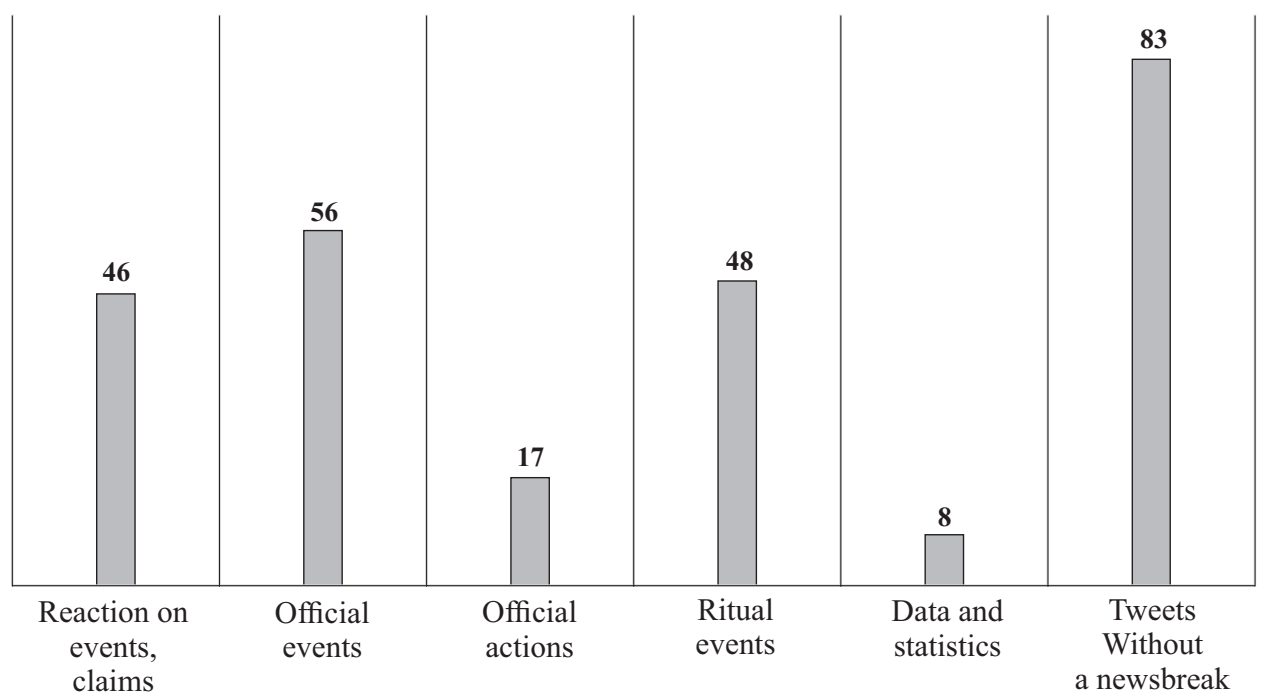

Source: Automated content analysis of Poroshenko's Tweets by Vicinitas Twitter analysis tool on August 2, 2019.

cians mostly were not represented in Azov Crisis dialogue; only some "diplomats" (without specification) were mentioned. Here, of course, Poroshenko is represented as the only person capable of resisting Putin and Russia.

The majority of Tweets about official events were published in November-December; thus other topics were used to attract attention towards the issue. Here, mainly ritual purposes were exploited: celebrations of national holidays (Infantry Day, Paratrooper Day, Crimean Tatar Flag Day), anniversaries (the annexation of Crimea or the War in Donbas battles), historic events (Battle of Kruty, Cossacks' battles, Central Rada creation in 1917 etc.). Here again mentions of Ukrainian politicians or institutions (except military and special services) were quite rare. The president, the common people, and the military were represented. For instance, Poroshenko and the military, honored with awards. Additionally, messages about the integrity of Ukrainians were spread: "Grateful for all the 5 years of Ukrainians' integrity from all the parts of the world."

Thus, speaking about the most popular categories of Tweets about the aggression, one can see Poroshenko as a leader both on international and domestic scene; however, he appeared without any political supporters. And while the international community is highly represented, with politicians and international institutions as the UN, NATO, the US Senate, Transparency International, G-20, Bloomberg, DW, European Council etc., for Ukraine we only see several mentions of institutions (the Parliament, the Navy, the Security Council, SBU) and politicians (Zelensky, former prime ministers (Groysman, Yatsenyuk), Kuchma and Yanukovych).

As for Poroshenko's reaction to claims and events, we see the same picture: he thanks international leaders for their support, appeals for help, but refers to Ukrainian political actors quite rarely. 
It's also possible to define the main topics of former Ukrainian president's Tweets by category (see fig. 3)

Fig. 3. Poroshenko's Tweets' (reaction to events, claims) main topics (Western countries and Russia)

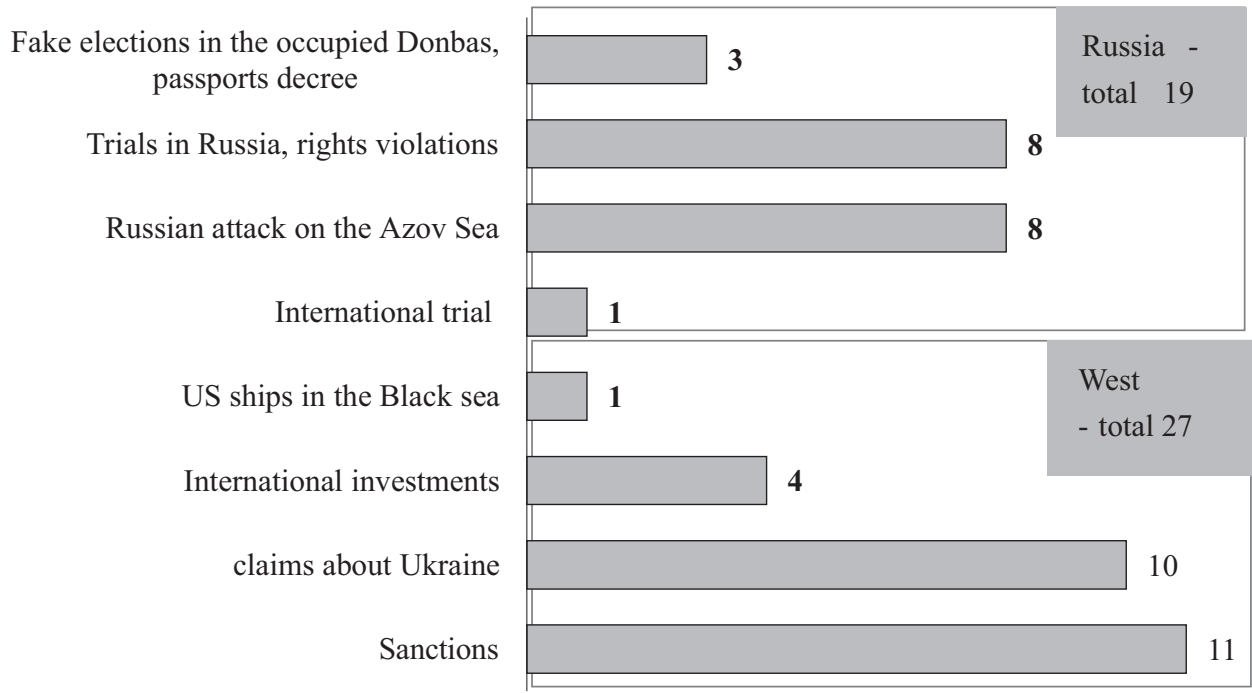

Source: Content analysis of Poroshenko's Tweets collected with Vicinitas Twitter analysis tool on August 2, 2019 .

Poroshenko pays great attention to mentioning Russian actions and international reaction to various events in Ukraine and abroad. To deal with the challenges posed by the Russian government, former president appealed not to Russian officials, but to international politicians. In some of these Tweets, he uses mentions (@) to tag the leaders, calling them "friends," and using group photographs with said politicians, but has never tagged Russian ones (for instance, Russian opposition). According to Poroshenko, de-escalation of the Russian-Ukrainian conflict is only possible with support from the international community; direct talks with Russian leaders are thus off the list.

Speaking about the category of Poroshenko's direct actions as president, the number of Tweets in it isn't large. His international activity, participation in various events (in Ukraine and abroad) seems to be more significant. Obviously, popular international leaders (such as Merkel or Grybauskaite) as well as domestic figures (military, volunteers) can be mentioned in order to improve both decreasing presidential rating and the decreasing interest towards the War in Donbas as a news topic. Moreover, Ukrainian diplomatic activity during Poroshenko's presidency is represented as great achievement of the former Ukrainian leader and his associates.

The last category - data and statistics - isn't prominent; as is however generally quite common in Twitter writing.

Thus, Poroshenko's Tweets mainly contain clear newsbreaks. However, in his Tweets without ones, he actively exploited topics of threats and insecurity. The former 
Ukrainian president frequently tried to remind the public that danger is around the corner and Russia is ready for a next provocative step.

For instance, he referred to "the numerous divisions put by Putin near our borders" and highlighted that new units were being gathered there. There were also several Tweets where the former president claimed that the aggression, the occupation, violence, and violation of human rights continued as Russia was not interested in final de-escalation of the conflict. Poroshenko characterizes Russia and Putin as "aggressive, unbalanced, but quite predictable," stressing the probability of aggression of an impulsive person. The enemy is "indifferent" to the losses (from both Russian and Ukrainian side). The former president's intentions are to present Russia as an emotionally unstable country, underlining that Ukraine may expect an act of aggression at any moment and demonstrating the enemy's weakness.

As a result, Poroshenko repeats his conclusion: "we should keep the powder dry and be ready to fight off the aggressor at any moment."

As we've already shown, Poroshenko mentioned Ukrainian political actors quite rarely; however, in his Tweets without newsbreak he constantly exploited the issue of "the $5^{\text {th }}$ column." Thus, his Ukrainian supporters weren't highly represented, but opponents were. The main characteristic of people associated with the $5^{\text {th }}$ column was their incorrect and even dangerous understanding of peace on Russia's conditions. At first Poroshenko didn't use any names, and was only mentioning "populists." Subsequently, after the first round of elections, when it was announced that Poroshenko and Zelensky would compete for the post, in the numerous Tweets the new candidate was accused of possible connection with Russia. As a result, Poroshenko perceives the elections as a fight against Putin and Russia (and Zelensky as a potential Kremlin agent) - for independence, unity and sovereignty. Poroshenko used the same approach during parliamentary elections (but not against Zelensky's party; he declared the Opposition platform and the Opposition block - with former members of Yanukovych's "Party of Regions" - his main opponents). He also claimed that his team was an object of constant attacks from "the Russian 5th column and the aggressor country."

To sum up, Tweets without newsbreaks are usually used to refer to threats to Ukrainian security, and to ensure everyone that with a strong leader and international support Ukraine could resist.

The War in Donbas is considered to consist of two phases: the "hot" phase (between the beginning of the aggression in 2014 and the $2^{\text {nd }}$ Minsk agreements in February of 2015) and the "cold" phase (after the agreements). However, the Minsk agreements didn't bring peace to Ukraine. The shelling continued as the number of deaths among civilians and the military grew. For Ukrainian mass media, the War in Donbas was much more interesting or newsworthy during the hot phase, but after 2015 there was a decrease in publications on the topic. Regardless, Poroshenko persisted to remind the public that the aggression is not over, Ukraine is not secure and the possibility of Russian invasion is still high. 
According to the hypothesis of this research, it was expected to define two manners of aggression exploitation in Poroshenko's Tweets. With the help of formal analysis, five categories of Tweets with newsbreak were found, and Tweets without newsbreak were defined. For all the Tweet categories, special vocabularies with lists of political actors, keywords and other identifiers were composed. Thus, in the majority of cases it's possible to identify the newsbreak with formal analysis of the reference (to a political actor, keywords of other identifier mentions). However, there are some limitations in the case of Tweets about Russia, because the metaphoric use of language is quite frequent; thus, manual processing was used for this purpose.

As for Tweets with and without newsbreak dissemination, the hypothesis wasn't confirmed: both Tweet types were used constantly. Some peculiarities can, however, be defined.

Tweeting during hot events was an everyday activity with a large number of Tweets for a long period. In comparison, during the pre-election period, special attention to the topics of foreign aggression and insecurity was directed; however, the mentions were distributed differently:

- One-three specially designated events with a large number of mentions, but the days before and after the events didn't have many mentions about the aggression;

- Constant attention towards "the aggression" (one mention per one-three days) with a small number of mentions per day.

As for special occasions meant to justify the purpose of mentioning aggression, traditional subjects dominated: meetings, ceremonies, etc. This seems to had been attempts to present an important topic during predictable scheduled events. As a result, the term "aggression" is mainly exploited not as a direct reaction to particular actions, but as reference to latest events.

The former president tried to represent himself as a moderator of international discussion of Russia's actions. Additionally, Poroshenko's attention towards anniversaries and honoring of the dead are steps to creation of modern Ukrainian mythology about the Russian-Ukrainian war. However, the former Ukrainian president showed preference towards international leaders and as a rule didn't specify Ukrainian politicians or institutions (only opponents; "the $5^{\text {th }}$ column" as a threat to the country's security was represented). Within Ukrainian politics it thus was him who resisted Russian aggression. He created an image of international community, integrated with Ukraine, but there are no mentions of a comparable community within Ukraine itself. Ukrainian society was shown as absolute unity without any contradictions.

Moreover, Poroshenko's type of tweeting has only some similarities with widespread understanding of political communication via social networks. For instance, the majority of his Tweets has a newsbreak; thus, former Ukrainian president's style of communication can't be described as unpredictable (Schneiker, 2019). Scheduled events, such as official visits/meetings or celebrations/commemorations, are mentioned quite often. Writing about meetings, telephone conversations etc., Porosenko uses mentions, which contradicts previous findings about underusage of social networks' features by politicians (Guerrero-Solé, 2018). 
Authentic language and amateurism (Pain, Chen, 2019), rule breaking (Schneiker, 2019), uncivility and impoliteness (Ott, 2017) aren't typical for Poroshenko either. Speaking about Russian aggression, he concentrates on international norms violations.

In the end, "polarization" (Matuszewski, Szabó, 2019) of political discourse emerged, especially evident before the second round of elections, when polls were predicting victory for Poroshenko's opponent. To attract public attention in highly competitive (Zhang, et al., 2019) "hybrid" media system (Chadwick, 2013), mentioning foreign aggression and the country's insecurity becomes a way to mobilize voters.

It is thus possible to conclude that there are different styles of political tweeting, and it would be counterproductive to use somt politician's tweeting style as benchmark for international political communication. Poroshenko relies on more traditional and pragmatic approaches to political communication via new media. However, in the atmosphere of distrust towards government in Ukraine, lack of integral unity, these approaches were not successful, and the voters chose the amateur president with no political experience.

\section{REFERENCES}

Baldwin-Philippi J. (2019), The technological performance of populism, "New Media \& Society", 21 (2).

BBC (2019), Editorial Guidelines, https://www.bbc.com/editorialguidelines (4.04.2020).

Blassnig S. et al. (2019), Populism in Online Election Coverage, "Journalism Studies", 20 (8).

Bossetta M. (2018), The Digital Architectures of Social Media: Comparing Political Campaigning on Facebook, Twitter, Instagram, and Snapchat in the 2016 U.S. Election, "Journalism \& Mass Communication Quarterly", 95 (2).

Broersma M., Graham T. S. (2013), Twitter as a news source: How Dutch and British newspapers used Tweets in their news coverage, 2007-2011, "Journalism Practice", 7 (4).

Camaj L., Northup T. (2019), Dual-Screening the Candidate Image during Presidential Debates: The Moderating Role of Twitter and Need to Evaluate for the Effects on Candidate Perceptions, "Journal of Broadcasting \& Electronic Media", 63 (1).

Cappelletti A. (2019), Between Centrality and Re-scaled Identity: A New Role for the Chinese State in Shaping China's Image Abroad: The Case of the Twitter Account, "Chin. Polit. Sci. Rev.", 4 (3).

Dogu B., Mat H. O. (2019), Who Sets the Agenda? Polarization and Issue Ownership in Turkey's Political Twittersphere, "International Journal of Communication", 13.

Entman R. (2003), Cascading Activation: Contesting the White House's Frame After 9/11, "Political Communication", 20.

Ernst N. et al. (2019), Populists Prefer Social Media Over Talk Shows: An Analysis of Populist Messages and Stylistic Elements Across Six Countries, "Social Media + Society", https://doi. org/10.1177/2056305118823358.

Ernst N., Esser F., Blassnig S., Engesser S. (2019), Favorable Opportunity Structures for Populist Communication: Comparing Different Types of Politicians and Issues in Social Media, Television and the Press, "The International Journal of Press/Politics", 24 (2).

Fukuyama F. (2018), The Demand for Dignity and the Politics of Resentment, New York. 
Garcia-Ortega C., Zugasti-Azagra R. (2018), The management of the candidates' Twitter accounts in the Spanish 2016 general elections: Between self-referentiality and media hybridization, "El Profesional de la Información", 27 (6).

Genovese F. (2019), International Crises and Political Patterns of Papal Tweets, "Political Science \& Politics", 52 (1).

Gerbaudo P. (2015), Populism 2.0: Social Media Activism, the Generic Internet User and Interactive Direct Democracy, in: Social Media, Politics and the State. Protests, Revolutions, Riots, Crime and Policing in the Age of Facebook, Twitter and YouTube, New York-London.

Guerrero-Solé F. (2018), Interactive Behavior in Political Discussions on Twitter: Politicians, Media, and Citizens' Patterns of Interaction in the 2015 and 2016 Electoral Campaigns in Spain, "Social Media + Society", https://doi.org/10.1177/2056305118808776.

Heiss R., von Sikorski C., Matthes J. (2019), Populist Twitter Posts in News Stories: Statement Recognition and the Polarizing Effects on Candidate Evaluation and Anti-Immigrant Attitudes, "Journalism Practice", 13.

Kelm O., Dohle M., Bernhard U. (2019), Politicians'Self-Reported Social Media Activities and Perceptions: Results From Four Surveys Among German Parliamentarians, "Social Media + Society", https://doi.org/10.1177/2056305119837679.

Lee J., Xu W. W. (2018), The more attacks, the more Retweets: Trump's and Clinton's agenda setting on Twitter, "Public Relations Review", 44 (2).

López-Rabadán P., Mellado C. (2019), Twitter as a space for interaction in political journalism. Dynamics, consequences and proposal of interactivity scale for social media, "Communication \& Society", 32 (1).

Matuszewski P., Szabó G. (2019), Are Echo Chambers Based on Partisanship? Twitter and Political Polarity in Poland and Hungary, "Social Media + Society", https://doi.org/ 10.1177/2056305119837671.

McGranahan C. (2019), A Presidential Archive of Lies: Racism, Twitter, and a History of the Present, "International Journal of Communication", 13.

McLaughlin B. (2019), Becoming a Presidential Candidate: Social Media Following and Politician Identification, "Mass Communication and Society", 22 (5).

Ott B. L. (2017), The age of Twitter: Donald J. Trump and the politics of debasement, "Critical Studies in Media Communication", 34 (1).

Pain P., Chen G. (2019), The President Is in: Public Opinion and the Presidential Use of Twitter, "Social Media +Society", https://doi.org/10.1177/2056305119855143.

Park C. S., Kaye B. K. (2019), Expanding Visibility on Twitter: Author and Message Characteristics and Retweeting, "Social Media + Society", https://doi.org/10.1177/2056305119834595.

Pérez-Curiel C., Naharro P. L. (2019), Political influencers. A study of Donald Trump's personal brand on Twitter and its impact on the media and users, "Comunicacion y Sociedad", 32 (1).

Schneiker A. (2019), Telling the Story of the Superhero and the Anti-Politician as President: Donald Trump's Branding on Twitter, "Political Studies Review", 17 (3).

Spierings N., Jacobs K. (2019), Political parties and social media campaigning: A qualitative comparative analysis of parties' professional Facebook and Twitter use in the 2010 and 2012 Dutch elections, "Acta Politica", 54 (1).

Stetka V., Surowiec P. (2019), Facebook as an Instrument of Election Campaigning and Voters' Engagement: Comparing Czechia and Poland, "European Journal of Communication", 34 (2).

Tari Z. G., Emamzadeh Z. (2018), An Analysis of the Media Messages during the 2016 U.S. Presidential Election: A Thematic Comparison between CNN News and Donald Trump's Tweets, "Journal of Politics and Law", 11 (2). 
Thompson M. (2016), Enough Said: What's Gone Wrong with the Language of Politics?, New York. van Aelst P. et al. (2017), Political Communication in a High-Choice Media Environment: A Challenge for Democracy?, "Annals of the International Communication Association", 47.

Villar S., María J. (2019), The use of blogs as social media tools of political communication: citizen journalism and public opinion 2.0, "Communication \& Society", 32 (1).

Zhang Y. et al. (2019), Whose Lives Matter? Mass Shootings and Social Media Discourses of Sympathy and Policy, 2012-2014, "Journal of Computer-Mediated Communication", 24 (4).

Zhang Y., Wells C., Wang S., Rohe K. (2018), Attention and amplification in the hybrid media system: The composition and activity of Donald Trump's Twitter following during the 2016 presidential election, "New Media \& Society", 20 (9).

\begin{abstract}
In modern political discourse, the topics of foreign aggression and insecurity are strongly influencing voter perceptions. In the unpredictable and polarizing environment of Twitter, references to crisis events may be used without justification. The character of tweeting during the peak phase of a crisis may differ, and it is possible to identify such differences analyzingthe tweets.

To compare the pre-election period with the period of foreign aggression, and to study the manner of tweeting of a political leader, the Twitter account of the fifth Ukrainian president Petro Poroshenko was observed between November 2018 (Azov crisis) and July 2019 (early presidential election). A total of 2,519 tweets were content-analyzed (the character of references to Russian aggression, newsbreaks, intensity, language justification were studied).

Tweeting during the Azov crisis was an everyday activity with a large number of tweets over a long period. Pre-election tweeting included commenting on specially created events (commemorations, celebrations) with a large number of mentions for short periods of time and constant online presence with a small number of tweets posted even without a special occasion.

Approximately one out of three tweets was written without reference to any newsbreak. Among the most popular newsbreaks, traditional subjects dominated (meetings, signings of laws etc.). Thus, the term "aggression" was mainly exploited during specially created events after the crisis.

Additionally, the stylistic features (authentic language, amateurism, unpredictability, breaking rules, incivility and impoliteness) that are widespread across social networks arenot typical of Poroshenko. A "polarization" of the political discourse, however, emerges. It is possible to observe it especially before the second round of elections, when the polls were predicting victory to Poroshenko's opponent.
\end{abstract}

Keywords: modern political discourse, Twitter, Poroshenko, Ukraine, foreign aggression, Azov crisis

\title{
PROPAGOWANIE POCZUCIA BRAKU BEZPIECZEŃSTWA NA TWITTERZE: POSTY PREZYDENTA UKRAINY I WSPÓLCZESNY DYSKURS POLITYCZNY
}

\section{STRESZCZENIE}

We współczesnym dyskursie politycznym tematyka agresji zagranicznej i braku bezpieczeństwa silnie wpływa na percepcję wyborców. W nieprzewidywalnym i polaryzującym śro- 
dowisku Twittera bez uzasadnienia można się odnosić do wydarzeń kryzysowych. Rodzaj tweetów zamieszczanych w szczytowej fazie kryzysu może być różny, co można stwierdzić drogą analizy.

Porównując okres poprzedzający wybory z okresem zagranicznej agresji i badając sposób w jaki tweetował przywódca polityczny, od listopada 2018 r. (kryzys azowski) do lipca 2019 r. (przedterminowe wybory prezydenckie) obserwowano konto piątego prezydenta Ukrainy Petra Poroszenki na Twitterze. Przeanalizowano pod względem treści w sumie 2519 tweetów (zbadano charakter odniesień do rosyjskiej agresji, doniesień prasowych, intensywność i język).

Podczas kryzysu azowskiego tweetowanie odbywało się codziennie przyjmując formę dużej liczby tweetów zamieszczanych przez długi czas. Tweetowanie przedwyborcze obejmowało komentowanie specjalnie stworzonych wydarzeń (rocznice, uroczystości) poprzez dużą liczbę wzmianek przez krótkie okresy i stałą obecność w Internecie, kiedy zamieszczano niewielką liczbę tweetów nawet bez specjalnej okazji.

Około jedną trzecią tweetów zamieszczono bez odniesienia do jakichkolwiek wydarzeń. Wśród najpopularniejszych wydarzeń dominowały tematy tradycyjne (spotkania, podpisywanie ustaw itp.). Dlatego też termin ,,agresja” był używany głównie podczas specjalnie stworzonych wydarzeń po kryzysie.

Ponadto stwierdzono, że języka Poroszenki nie charakteryzują typowe dla sieci społecznościowych cechy stylistyczne (autentyczny język, amatorstwo, nieprzewidywalność, łamanie zasad, nieuprzejmość i brak manier). Pojawia się jednak ,polaryzacja” dyskursu politycznego. Można to zaobserwować zwłaszcza przed drugą turą wyborów, kiedy sondaże zapowiadały zwycięstwo przeciwnika Poroszenki.

Słowa kluczowe: współczesny dyskurs polityczny, Twitter, Poroszenko, Ukraina, obca agresja, kryzys azowski 
